\title{
Dragon Fruit in Nepal
}

\section{Swodesh Rijal}

Faculty of Agriculture, Agriculture and Forestry University, Rampur, Chitwan, Nepal

*Corresponding Author Email: swodeshrijal@gmail.com

\section{Doi: 10.2478/mjhr-2019-0010}

\begin{abstract}
:
Dragon fruit is a cactus species which is indigenous to Americas belongs to Genus Hylocereus. Dragon fruit is commonly known as Noble woman, Pitahaya, strawberry pear, Super fruit etc. It has antioxidant properties which prevents oxidation of cholesterol. Similarly, dragon fruit contains phytonutrient, minerals and vitamins which are beneficial to blood, tissue, bone and overall health. On research it was found out that Lycopene which is responsible for red colour in dragon fruit has been linked with a lower prostate cancer risk. Nowadays it is widely used in restaurant as fruit salad, refreshing drinks, Jams, Ice creams, Jelly, fruit juice, wine etc. In Nepal, Mr. Jagannath Rai brought dragon fruit from USA in 2057 B.S. and later Gorkha Millenium multipurpose cooperatives ltd formally started cultivation of dragon fruit in commercial level from 2070 B.S (2013 A.D). In Nepal there is a wide scope for cultivation as it can cultivate in region of less rainfall at altitude of 1500 from MASL. Availability of Fallow and marginal lands of Terai, Bhitri madhes, valleys and lower range of mountain are suitable for cultivation. Moreover, there are great possibilities of production of organic dragon fruits. Inspite of various benefits and possibilities, farmers' condition and investment are major challenges for exploration of dragon fruit in Nepal.
\end{abstract}

Keywords: Dragon fruit, Importance, Scope, Challenges

\subsection{Introduction:}

Dragon fruit is a climbing vine type of Cactus species indigenous to Americas [1]. It is commonly nicknamed as "Noble woman" and it was believed that by eating it one became empowered with same strength of a dragon. Dragon fruit belongs to Genus Hylocereus [2]. Dragon fruit is called as the most beautiful in cactus and others names of it are Pitahaya, strawberry pear, papipi pua. Pitahaya is cultivated and well established in Southeast asia (Vietnam, Taiwan, China, Israel, Malayasia), Australia, Florida and others tropical and subtropical regions of world [3].

\subsection{Methodology}

This paper is based on reviewing of various articles.

\subsection{Importance}

Dragon fruit rich in antioxidants [5], contain phytonutrient [6], 12 different minerals and vitamin (vit C as equivalent to $10 \%$ of daily value and several B vit). An antioxidant property prevents oxidation of cholesterol. Due to antioxidants properties people often called dragon fruit as a "super-fruit". It contains minerals like Iron, phosphorus makes healthy blood and tissue, Ca present in it makes strong bone \& teeth [7]. Lycopene which is responsible for red colour has been linked with a lower prostate cancer risk [8]. Similarily, it provides Essential fatty acid. It was found that seeds of dragon fruit are best for providing omega-3 and omega-6 fatty acid [9] that reduces cardiac stress [10]. Not only in human health, it is widely used in restaurant as fruit salads [11], best eaten chilled or blended into refreshing drinks also. Jams, Ice creams, Jelly, fruit juice, wine etc are dragon fruit-eating products.

Nutrients: United states Department of Agriculture provided data in label form as manufactures are responsible and calculated values per $100 \mathrm{~g}$ from values per serving.

Nutritional value per $100 \mathrm{~g}$

\begin{tabular}{ll}
\multicolumn{2}{c}{ Nutritional value per $100 \mathrm{~g}$} \\
\hline Energy & $268 \mathrm{kcal}$ \\
Carbohydrates & $82.14 \%$ \\
Protein & $3.57 \%$ \\
Vitamin c & $9.2 \mathrm{mg}$ \\
Calcium & $107 \mathrm{mg}$ \\
Sodium & $39 \mathrm{mg}$ \\
\hline
\end{tabular}

Source: [12]

\subsection{History in Nepal}

For the first time in Nepal Veterinary Doctor Mr. Jagannath Rai brought dragon fruit from USA through his friend in 2057 B.S. for the decade it is just in information. Gorkha Millenium multipurpose cooperatives ltd formally started cultivation of dragon fruit in commercial from 2070 B.S (2013 A.D) [13]. Nowadays, commercial cultivation of it going in jhapa and dhankuta district of Nepal but just for trial.

\subsection{Scope in Nepal}

Dragon fruit is famous in Vietnam, Thailand, Israel and Srilanka. In Nepal commercial cultivation is just in starting phase. Present market price of this fruit in Nepal is Rs 800 to 1000 per kg $(7.16 \$$ to $8.95 \$)$. This fruit can cultivate in region of less rainfall at altitude of 1500 from MASL. There are availability of thousand of fallow and marginal land in Terai, Bhitri madhes, valley and lower range of mountain which are suitable for cultivation. The chemical fertilizer demand of Dragon fruit is less. Nepalese farmers are unable to effort chemical fertilizer in higher altitude. So, we could grow organically using our local manures like FYM, Compost, vermicompost which results into economical and eco-friendly production. Moreover, Organic dragon fruit can considerably raise price received for it [14]. In spites of having various benefits and advantage still as underutilized crops and considered as fruit for future [15]. Dragon fruit add value of agro-tourism. Dragon fruit has great importance in Nepal as it is beneficial for Small landholder marginal farmers and to improve livelihood of them. It may become the good foreign currency earning ways in future. So, dragon fruit is fruit for future Nepal.

\subsection{Challenges}

For cultivation, initial investment is higher as compare to others crop. Normal Nepalese farmers are unable to invest huge money because agriculture itself a risk business. So, government must provide subsidy, training, related various extension works thro ugh NARC, INGOs, NGOs for better result.

\section{References}

[1] J. Morton, "Strawberry pear In: Fruits of warm climates", Center for New Crops \& Plant Products, west lafayette: Purdue University, Department of Horticulture and Landscape Architecture, 347-348, 1987.

[2] J. Crane, and C. Balerdi, “Dragon fruit. Gainsville: Institute of Food and Agricultural Sciences University of Florida”, IFAS Extension, 2004. 
[3] E. Small, “Top 100 Exotic food Plants”, Boca rotan: CRS Press, 2012.

[4] ISB., "Hylocereus undatus (Haw)”. Brit. \& Rose edn. USA: Institute for Systematic Botany, 2002.

[5] https://pubs.acs.org/action/showCitFormats?doi=10.1021\%2Fjf060566s

[6] H. Kim, H.K. Choi, J.Y. Moon, Y.S. Kim, A. Mosaddik, and S.K. Cho, "Comparative antioxidant and antiproliferative activities of red and white pitayas and their correlation with flavonoid and polyphenol content", Journal of food science, Vol. 76 (1), 38-45, 2011.

[7] K.V. Peter, Underutilized and Underexploited Horticultural crop. New Delhi: New India Publishing Agency, 4, 2008.

[8] P. Chen, W. Zhang, X. Wang, K. Zhao, D.S. Negi, L. Zhuo, M. Qi, X. Wang, and X. Zhang, "Lycopene and Risk of Prostate Cancer: A Systematic Review and Meta-Analysis", Medicine (Baltimore), Vol. 94 (33), e1260, 2015.

[9] A.A. Ariffin, J. Bakar, C.P. Tan, R.A. Rahman, R. Karim, and C.C. Loi, "Essential fatty acids of pitaya (dragon fruit) seed oil”, Food Chemistry, Vol. 114 (2), 561-564, 2009.

[10] M. Clinic, "Dietary fats: know which types to choose", Healthy lifestyle Nutrition and healthy eating, 2016.

[11] L. Luders, "The pitaya or Dragon fruit (hylocereus undatus)”, Agnote 778 No. D 42 Northern Terriority of Australia, 2004.

[12] USDA, “Dragon fruit”, United States Department of Agriculture, 2018.

[13] Gorkha Millenium Cooperatives Ltd. retrieved: https://gurkhaml.com/

[14] C.B. Randall, "Business, Economics and Jobs", Dragon Fruit Makes its culinary journey to US Farms and Kitchens PRI.

[15] H. Gunasena, and D. Pushpakumara, "Dragon fruit- Hylocereus undatus (Haw) Britton and Rose:a fruit for the future", Wijerama Mawatha Colombo 7 , Sri Lanka: Sri Lanka Council for Agricultural Policy, 2006. 